\title{
Polypore survey of Finland 3. The genera Coltricia, Inonotopsis, Inonotus and Onnia
}

\author{
TUOMO NIEMELÄ and HEIKKI KOTIRANTA
}

\begin{abstract}
NIEMELÄ, T. \& KOTIRANTA, H. 1983: Polypore survey of Finland 3. The genera Coltricia, Inonotopsis, Inonotus and Onnia. - Karstenia 23: 15-25.

Distribution maps are presented for the following polypore species in Finland: Coltricia cinnamomea (Jacq.: S.F. Gray) Murrill, C. perennis (L.: Fr.) Murrill, Inonotopsis subiculosa (Peck) Parmasto, Inonotus dryophilus (Berk.) Murrill, I. hispidus (Bull.: Fr.) Karst. (new to Finland), I. obliquus (Fr.) Pilát, I. radiatus (Sow.: Fr.) Karst., I. rheades (Pers.) Karst., Onnia leporina (Fr.) Jahn, O. tomentosa (Fr.) Karst. and O. triquetra (Lenz) Imazeki. The host plants are listed for each species, the ecology and pathogenicity of the species are discussed, and an evaluation made of their economic importance as pathogens and wood-rotting fungi on merchantable timber and ornamental trees and shrubs. Of these the most harmful species are Inonotus obliquus (especially on birch) and Onnia leporina (on spruce).

The concepts of the genera are briefly discussed, and some author citations are altered to accord with the Code of Nomenclature enacted in 1981.
\end{abstract}

Tuomo Niemelä \& Heikki Kotiranta, Department of Botany, University of Helsinki, Unioninkatu 44, SF-00170 Helsinki, Finland

\section{Foreword}

This is a continuation of the mapping of the polypores of Finland, started recently (Niemelä 1982). The first survey issue (Niemelä \& Kotiranta 1982) dealt with the genus Phellinus; the present issue comprises the other genera of the Hymenochaetales found in Finland.

We have kept the old generic division, although we acknowledge that it may be in some respects artificial. These problems are the subject of extensive studies in Lyon, France, with which we do not want to interfere. The genus Phaeolus (i.e., P. schweinitzii (Fr.) Pat.) has been excluded from the order, following Jülich (1981). For Coltricia and Onnia, we have followed the opinions of Jahn (1978). The most important deviation from the common practice (Donk 1974, Ryvarden 1976, 1978) is the exclusion of the genus Inonotopsis from the synonymy of Inonotus. This treatment is discussed under I. subiculosa (Peck.) Parm.

Several of the taxa dealt with here are important from the economic point of view. The spruce forests of Lapland are known for the especially heavy losses caused by decay. In our previour paper, Phellinus chrysoloma (Fr.) Donk was reported to contribute to these losses. Here we introduce another severe pathogen of northern spruces, Onnia leporina (Fr.) Jahn.

Other species probably occurring, though not yet recorded in Finland are Inonotus cuticularis (Fr.) Karst. and perhaps also I. dryadeus (Fr.) Murrill. For the wrong records of the latter, see Niemelä (1981).
The genera and species are arranged in alphabetical order. The author citations, given mainly according to the bibliographic information of Donk (1974), have been corrected to fit with the changes in the International Code of Botanical Nomenclature (Sydney Code). For the general terms used in this survey, the material included, etc., the reader is referred to the Introduction to this series (Niemelä 1982).

\section{Coltricia cinnamomea (Jacq.: S.F. Gray) Murrill \\ Rotten hardwood Specimens examined \\ A \\ $+$ \\ 1}

Known from a single locality in Finland. The find, reported by Schulmann (1955) from Åland: Eckerö, is undisputably C. cinnamomea and was accepted as such by Laine (1967). Later Schulmann (1960) reported another locality, Laatokan Karjala: Parikkala in SE Finland. We have studied the specimen (HFR 952), which is typical C. perennis.

The fruit bodies were reported to be growing on decayed wood and the specimens still have wood attached to the stipe. According to Dr. Maire Pyykkö (University of Helsinki), the wood remains definitely belong to a hardwood tree, most probably of the genus Betula. Although the species is generally reported to grow on bare soil, e.g., old campfire places, Marchand (1976) also mentions decayed deciduous wood as a substrate. 
The identity of this species has remained obscure for a long time. A reason has been the great morphological variation of $C$. perennis, since $C$. cinnamomea has sometimes been considered only an extreme of that species. As shown by Ryvarden (1976), however, C. cinnamomea is a distinct species, the chief diagnostic characters being the shape and width of the spores. The Finnish collection of $C$. cinnamomea has subglobose spores (6.0-) 7.0-8.0 (-8.3) × (4.8-) 5.5$6.0(-6.3) \mu \mathrm{m}$, while C. perennis (Finnish specimens)

\section{Coltricia perennis (L.: Fr.) Murrill}

\section{Whole of Finland}

Specimens

examined

\section{A-U}

EK-PK

KP-PP
116 has ellipsoid spores (7.0-) 8.0-8.5 (-8.9) $\times(3.8-)$ $4.0-4.6(-5.0) \mu \mathrm{m}$, young spores being common and shorter. The spores of both species are strongly cyanophilous and weakly dextrinoid. C. cinnamomea has wider and thinner-walled hyphae in all parts of the fruit body: the dissepiments of C. perennis commonly contain thick-walled hyphae between the thinwalled ones. This does not indicate dimiticity, since both types are septate and intermediate wall thicknesses are common.

Evenly distributed throughout Finland, very common or common wherever suitable sites are found.

This species has always been found growing on the ground, mostly in coniferous forests, but without any evident association with trees. The characteristic growth sites are sandy soils: paths, roadsides, and other places where the ground has been disturbed and then left relatively untouched for a few years. It seems that the species is slightly hemerophilous, benefiting by human influence. The commonest natural habitat is dry pine forest on glacial sandy terrain, where the mineral soil is barely covered by a scanty mat of lichens (e.g., Cladonia species) and undemanding moss species.
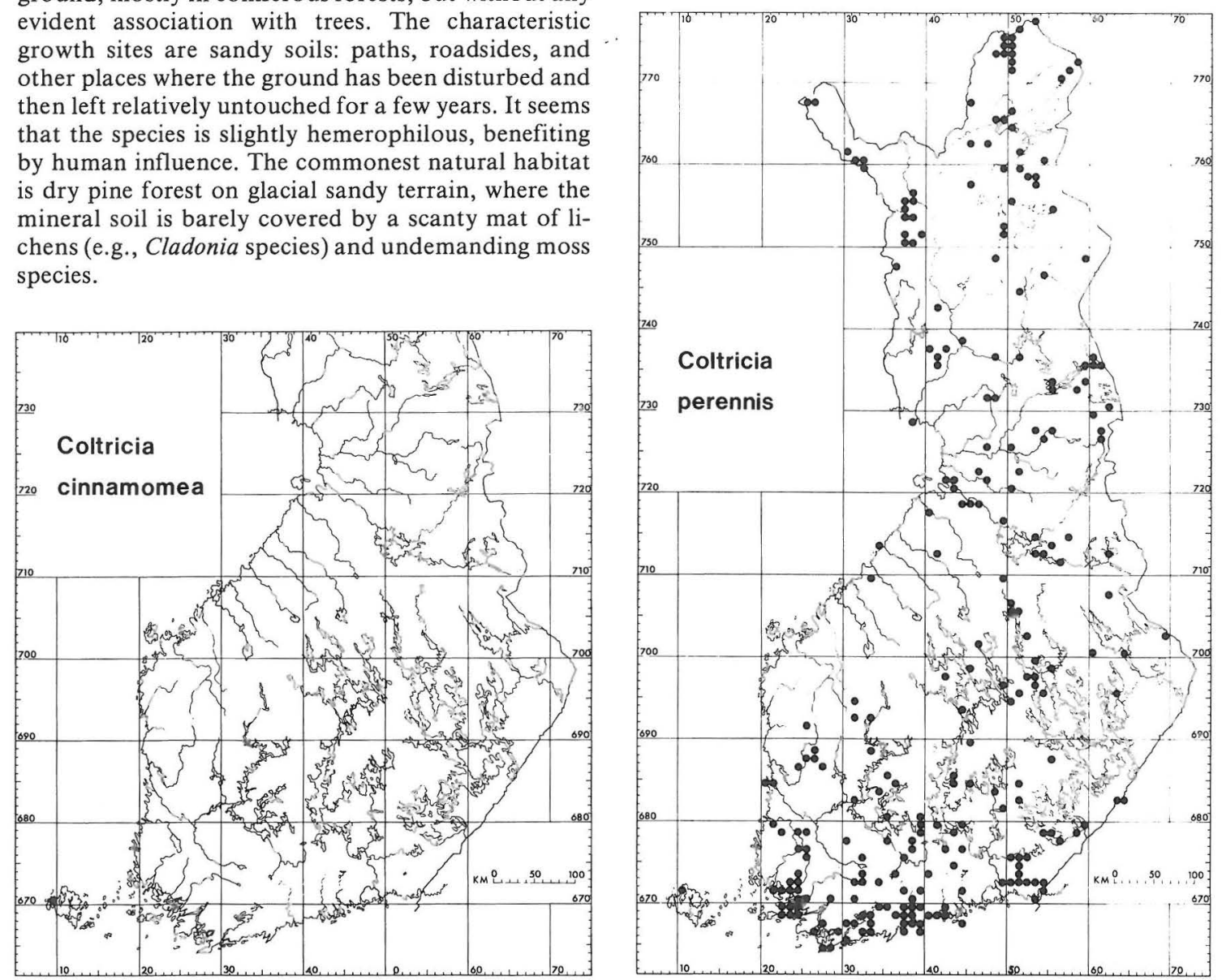
Inonotopsis subiculosa (Peck) Parmasto

PP

Picea abies

Specimens examined

$+$

1

In Finland known only from a single collection (in GB/John Eriksson herbarium) from Rovaniemi: Pisavaara Nature Reserve. The find was reported by Eriksson and Strid (1969) as Inonotus subiculosus (Peck) Eriksson \& Strid, and the specimen was illustrated and briefly described in the same paper. The species must be very rare in the area, because it has not been found again, although the same locality has been searched for many years. It is a rarity in Europe as a whole. Parmasto (1973) reported another locality in the Archangel Region: Plesetsk district, Yemtsa. No other records are known to us. It is more widely distributed in North America (Lowe 1966).

We support the retention of the species in a genus of its own, mainly because of the spore characters. The spores are very thin-walled, hyaline and acyanophilous or very weakly cyanophilous. The contents of the spores are tinted faint blue in Cotton Blue, and it is difficult to state the exact colouring of the membranaceous spore walls. In any case they are not strongly cyanophilous as in Inonotus or Coltricia. Externally I. subiculosa resembles Asterodon (except for the hymenial configuration), but the latter has strongly cyanophilous spores, and also differs in having narrow, fibre-like hyphae. As regards the spores, the species comes closest to Onnia, but being resupinate is best kept separate from it in Inonotopsis. The lack of setae in $I$. subiculosa does not in itself necessitate its separation from any Hymenochaetaceous genus.

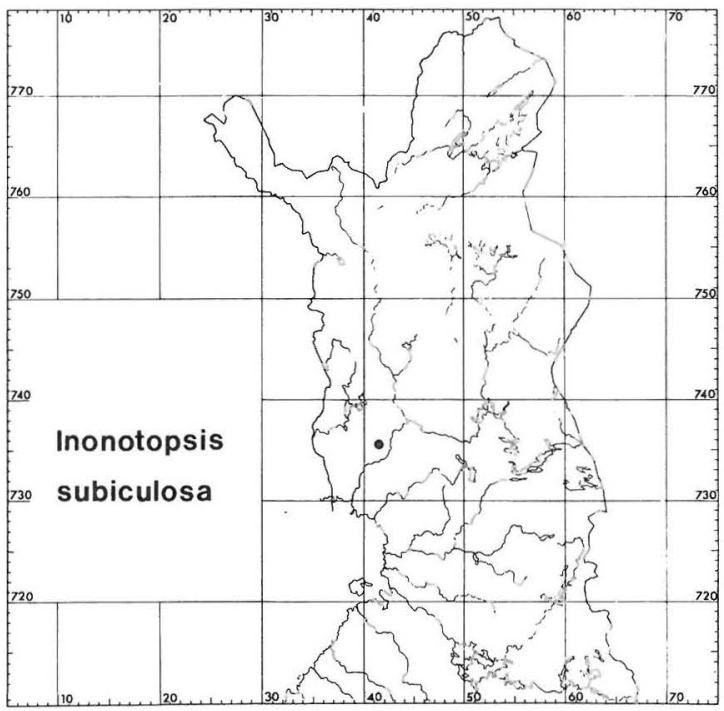

Inonotus hispidus (Bull.: Fr.) Karst.

$\begin{array}{lc} & \text { V } \\ \text { Fraxinus excelsior } & + \\ \text { Specimens examined } & 1\end{array}$

New to Finland. As indicated by Niemelä (1981), earlier reports of this species on oak in Finland should be referred to Inonotus dryophilus. The present specimen was heavily infected with moulds, having dried too slowly, but identifiable microscopically. The spores are ellipsoid, thick-walled, brown, (8.0-) $8.5-10.2 \times(5.5-) 6.5-7.5 \mu \mathrm{m}$, the tomentum and hymenium lack setae and there is no core. The spores are rather small for I. hispidus, but within the limits of the variation. I. dryadeus is ruled out by the following observations: The spores are not globose, there are no setae and the dissepimental hyphae are flexuous (not closely parallel as in I. dryadeus); further, the pores are $2-3$ per $\mathrm{mm}$ (3-5 per $\mathrm{mm}$ in I. dryadeus). According to the field notes, the underside and margin of the young fruit body were yellowish and sticky, and covered with droplets all round. The colour of the dried specimen is coffee brown. The fruit body was found growing on a branch joint on a standing trunk, close to the ground.

The European distribution of I. hispidus is concentrated in the Central and Mediterranean parts, and the species occurs on various deciduous hosts, especially in orchards and on trees planted along roads. In Scandinavia the main host is Fraxinus excelsior (Ryvarden 1978), which fits with the present find. The closest occurrences of the species are on the Swedish islands of Gotland and Öland.

Specimen examined. Finland. Varsinais-Suomi. Iniö, Åselholm, Fraxinus excelsior, 13.VIII.1982 Gustav Kvist (H).

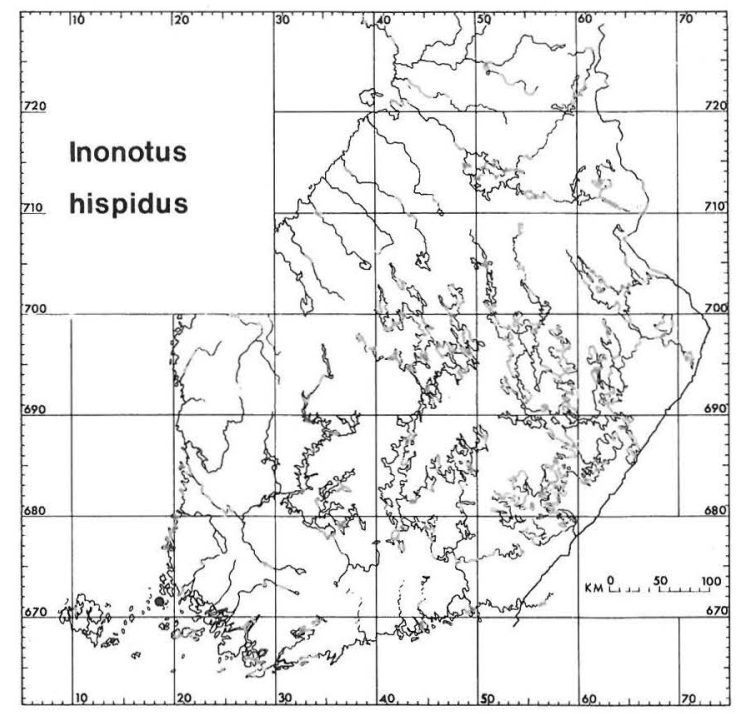




\section{Inonotus dryophilus (Berk.) Murrill}

$\begin{array}{lc} & \text { V } \\ \text { Quercus robur } & 100 \\ \text { Specimens examined } & 5\end{array}$

Two localities are known in Finland for I. dryophilus. The older one is in Varsinais-Suomi: Turku, Ruissalo (Runsala), on a single tree or a few trees growing close together. It was first recorded there by Karsten $(1882,1889)$, so that the species has survived in that locality for about a hundred years. The proper identity and the confusion about the names of this material were discussed by Niemelä (1981).

Another locality emerged rather recently (Turku, Muhkuri, coll. 1981 Reino Alava 19694, TUR). It is situated $5 \mathrm{~km}$ from the first, in a protected oak forest intermixed with Populus tremula and Corylus avella$n a$. The fungus was growing on a fairly young living oak, about two metres above the ground. This record falls within the same map square as the first one.

Inonotus obliquus (Fr.) Pilát

\begin{tabular}{lccccc} 
& $\begin{array}{c}\text { Whole of } \\
\text { Finland }\end{array}$ & A-U & EK-PK & KP-PP & Ks-InL \\
$\begin{array}{l}\text { Betula } \\
- \text { pubescens }\end{array}$ & 82.8 & 74.1 & 84.9 & 80.0 & 95.0 \\
- pendula & 13.1 & & & & \\
$\begin{array}{l}\text { Alnus } \\
- \text { incana }\end{array}$ & 11.6 & 15.5 & 11.8 & 20.0 & 5.0 \\
$-\begin{array}{l}\text { glutinosa } \\
\begin{array}{l}\text { Sorbus } \\
\text { aucuparia }\end{array}\end{array}$ & 3.1 & & & & \\
$\begin{array}{l}\text { Acer } \\
\text { platanoides }\end{array}$ & 3.0 & 8.6 & 2.5 & - & - \\
$\begin{array}{l}\text { Populus } \\
\text { tremula }\end{array}$ & + & - & + & - & - \\
$\begin{array}{l}\text { Host not } \\
\text { indicated }\end{array}$ & + & + & - & - & - \\
$\begin{array}{l}\text { Specimens } \\
\text { examined }\end{array}$ & 6 & & & & \\
\hline
\end{tabular}

The relative abundance of fruit bodies and imperfect knots as percentage:

$\begin{array}{llllll}\text { Fruit bodies } & 50.8 & 31.0 & 49.2 & 44.0 & 74.6 \\ \text { Imperfect knots } & 49.2 & 69.0 & 50.8 & 56.0 & 25.4\end{array}$

Distributed through the whole Finland, everywhere common or very common. The concentration of records in the southern Lake District reflects only locally intense collecting activity.

The species can be identified from both the fruit bodies (formed only after the death of the host tree) and from the imperfect knots it forms in living trees.

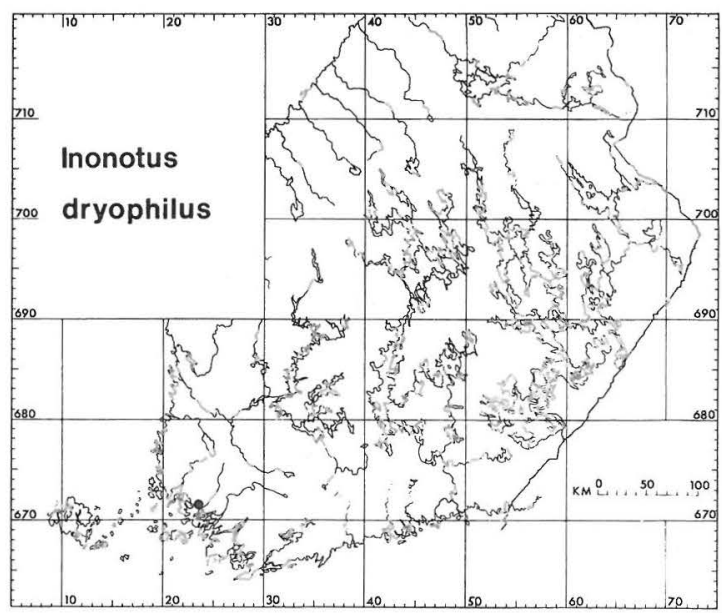

According to these records, $I$. dryophilus is very rare in Finland and restricted to the south-western, climatically most favourable part of the country.
About half of the herbarium specimens from the whole country represent fruit bodies, half imperfect conks. However, there are very distinct differences in their proportions in different regions. In southern Finland about two thirds of the finds belong to the imperfect stage, which reflects the real situation fairly well; fruit bodies are found only seldom. In Lapland, 
by contrast, about three quarters of the collections contain fruit bodies. There, they are often profuse and sometimes form luxuriant resupinate fructifications extending several metres along the birch trunks (Niemelä 1983), while the black knots are rather rarely seen.

The reason for this difference is not known. One explanation may be that in the south human activity often leads to the amputation of big branches from living trees, which favours infection and the formation of the imperfect knots. There, too, trees are removed as soon as they cease to thrive or soon after their death, i.e., before the fruit bodies can develop. Trees, especially birches, may also be able to resist the infecting fungus more strongly in southern Finland, so that only the conks are formed. In Lapland the trees may be more rapidly invaded by the mycelium, soon dying and thus giving the fungus an opportunity to fruit.

I. obliquus occurs in many kinds of biotopes. In southern and central Finland it prefers solitary, old trees, and the birches in parks, drives, boulevards and park-like suburbs. In Lapland it favours the Mountain birch in natural surroundings. All kinds of breaks in the bark seem to serve as a route for the invading fungus, but especially the stubs of big branches in the lower and middle parts of the stem. The abundance of thick branches in well-spaced, well-illuminated trees and the habit of sawing them off are surely reasons why this fungus is so common in the birches of the parks.

The occurrence on Alnus species is commoner in the south; these finds are mainly from disturbed young forests at an early stage of the succession. Phellinus tremulae is known to induce similar imperfect knots on Populus tremula (Černý 1972, Niemelä \& Kotiranta 1982). The single report of I. obliquus from that host is based on a fruit body and can therefore be regarded as reliable. The host itself, however, could not be confirmed. There is no reason to suspect the record from Acer platanoides: it is based on the find of a big, imperfect knot growing on a forestry school park tree, which was still living. The other polypores that form imperfect conks (Inonotus andersonii (Ell. \& Everh.) Černý, I. nidus-pici Pilát and Phellinus pilatii Černý; Černý 1959, 1965, 1968, 1982) do not occur in North Europe.

Being a strong parasite of deciduous trees, I. obliquus causes significant damage to Betula pubescens and $B$. pendula, especially in southern and Central Finland. The former is distinctly more susceptible to the fungus that the latter. Economically, however, the harm caused to $B$. pendula is more important, since it is superior in forestry and as a park tree. I. obliquus is the main reason why $B$. pendula is generally regarded as rather unsuitable for parks, due to its early decay. The harm caused to the birch veneer industry is also considerable.

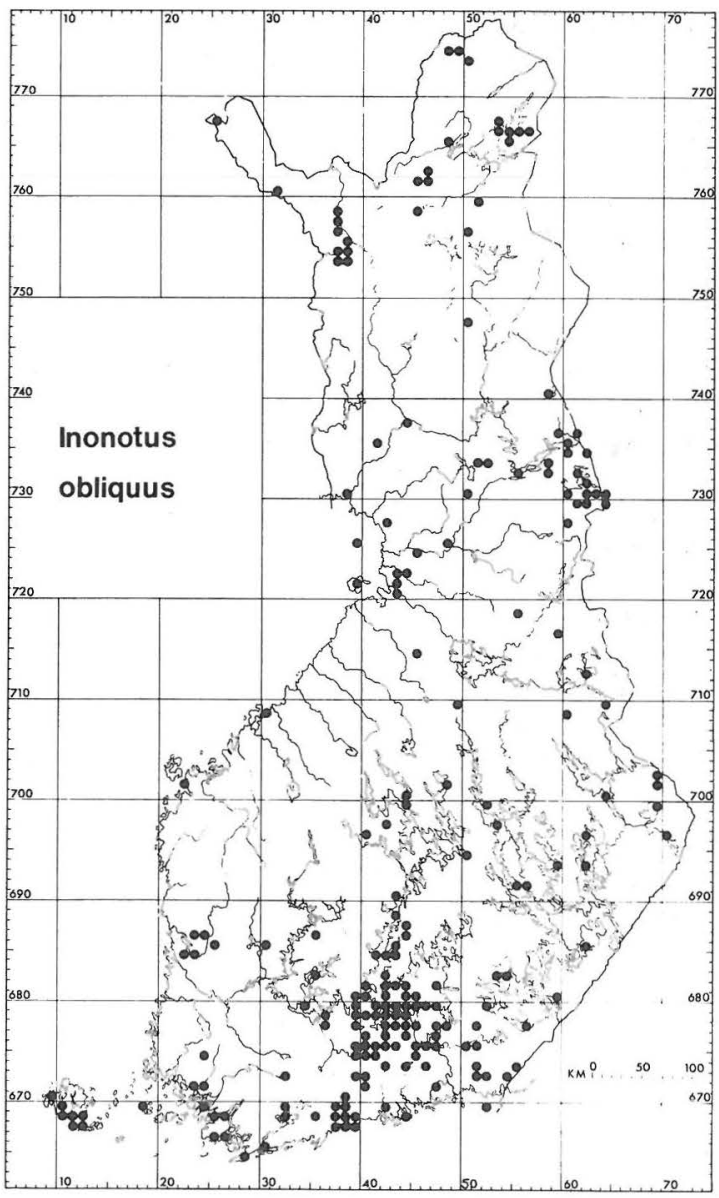

As a curiosity we may mention various uses of the imperfect knots of $I$. obliquus. Their use as a beverage (the caga tea) and medicine (Befungin) in the U.S.S.R. is fairly widely known (cf. Reid 1976), and a substance (a triterpene called obliquol) has been isolated from them that is active against sarcoma and carcinoma tumours (Kier 1961). The fungus was also utilised in Finland during the Second World War, being prepared and distributed by the Paasivaara Company under the trade name Tikkatee ('Woodpecker tea'). The black conks were first gathered, then washed, dried, and ground into pieces $1-4 \mathrm{~mm}$ in diameter. The product was sold as a substitute for tea, in similar packets, but the beverage was generally accepted as a brand of its own. It became very popular and was often asked for when distribution ceased after the end of the war. The drink was prepared by mixing the grains in cold water, which was then heated to near boiling-point. The solid material was strained away before serving. There are no records of true medicinal use in Finland. 
Inonotus radiatus (Sow.: Fr.) Karst.

$\begin{array}{lccccc} & \begin{array}{c}\text { Whole of } \\ \text { Finland }\end{array} & \text { A-U } & \text { EK-PK } & \text { KP-PP } & \text { KemL } \\ \text { Alnus } & 64.7 & 58.7 & 72.8 & 90.0 & - \\ \text { - glutinosa } & 31.6 & & & & \\ \text { - incana } & 19.7 & & & & \\ \text { Corylus avellana } & 16.8 & 26.9 & 2.5 & - & - \\ \text { Betula } & 7.8 & 5.0 & 12.7 & - & - \\ \text { - pubescens } & 1.7 & & & & \\ \text { - pendula } & 0.5 & & & & \\ \text { Syringa vulgaris } & 3.2 & 1.7 & 5.7 & - & - \\ \text { Prunus padus } & 1.9 & 1.2 & 3.2 & - & - \\ \text { Crataegus } & 1.5 & 2.0 & + & - & - \\ \text { Sorbus aucuparia } & 1.5 & 2.0 & + & - & - \\ \text { Salix } & 1.2 & 1.2 & - & + & - \\ \text { - caprea } & 0.5 & & & & \\ \text { - fragilis } & + & & & & \\ \text { Populus tremula } & 0.7 & + & 1.3 & - & - \\ \text { Quercus robur } & 0.5 & + & + & - & - \\ \text { Taxus cuspidata } & + & + & - & - & - \\ \text { Host not indicated } & 50 & & & & \\ \text { Specimens examined } 461 & 276 & 173 & 11 & 1\end{array}$

Distribution distinctly southern: very common in the Hemiboreal zone and in the southern half of the Southern boreal zone. Rare in the Middle boreal zone, and recorded only twice from the Northern boreal zone. Many host trees of I. radiatus occur in almost all parts of Finland, and so the southern character is considered to be directly due to climatic fac-. tors.

The species has a rather wide host spectrum in southern Finland. Alnus (particularly A. glutinosa) is the main host tree and in the marginal areas almost the exclusive one. Corylus avellana is a favourite host wherever it occurs, but owing to its southern distribution (roughly the same as the distribution of Acer platanoides, see Niemelä 1982: 23) accounts for only a small proportion of the records. Syringa vulgaris is also notably often infected. Relatively scattered occurrences are found on other deciduous trees, through Prunus padus is a constant host. The only record on a coniferous host in Finland is that on Taxus cuspidata, which is a park tree in Helsinki; the fruit bodies were found by the author Kotiranta on a dying trunk during several autumns.

A characteristic natural growth site of $I$. radiatus is an alder thicket close to a lake shore or small stream, especially if the ground is water-logged in the spring. In these sites it is a noteworthy parasite of alder trees, causing butt rot at an initial stage, killing the trees and finally decaying the trunks along their whole length. Dense stands of alder of ten support abundant occurrences, but $I$. radiatus can also be found on single trees. Another characteristic growth site is a hazel thicket in or bordering grass-herb forest. Everywhere the species seems to favour rather high local humidi-

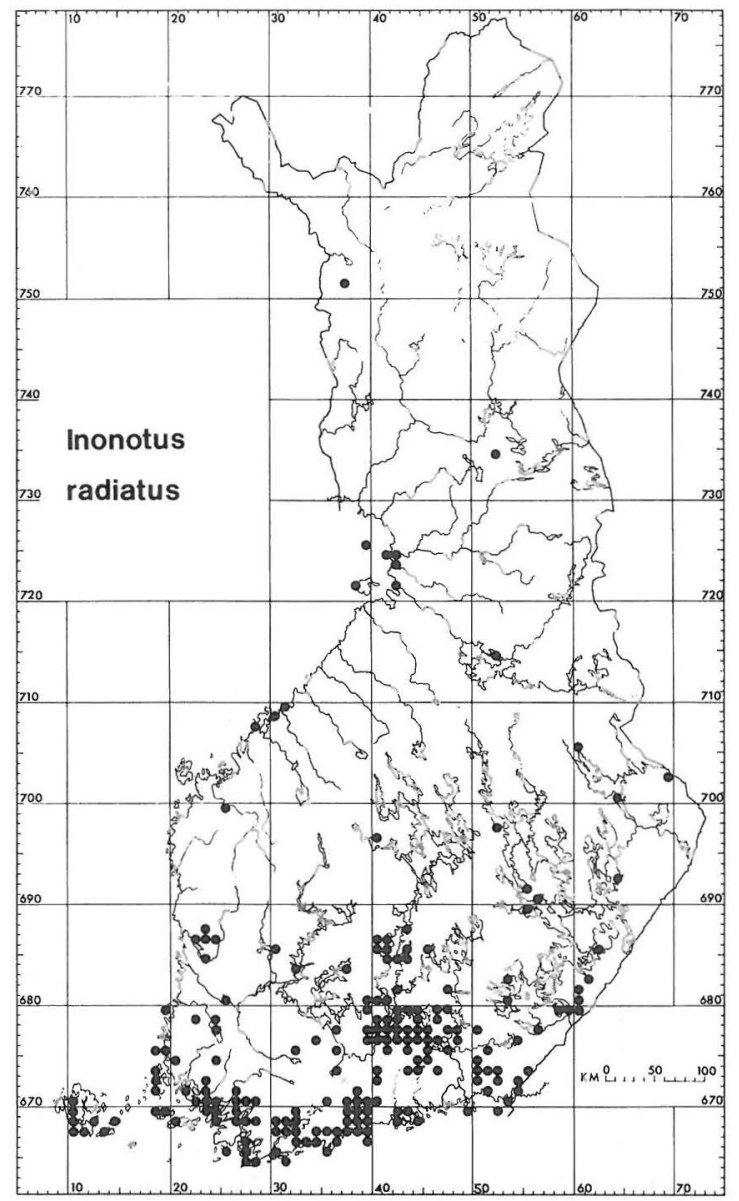


ty. The fruiting period in a single, dead host tree is only one or a few years. In southern Finland $I$. radiatus is often followed by Antrodiella hoehnelii (Bres.) Niemelä (Kotiranta \& Niemelä 1981).

In spite of its common occurrence in southern Fin-

Inonotus rheades (Pers.) Karst.

$\begin{array}{lccccc} & \begin{array}{c}\text { Whole of } \\ \text { Finland }\end{array} & \text { A-U } & \text { EK-PK } & \text { KP-PP } & \text { Ks } \\ \text { Populus tremula } & 98.0 & 97.4 & 97.6 & 100 & 100 \\ \text { Betula } & + & - & + & - & - \\ \text { Salix caprea } & + & - & + & - & - \\ \text { Tilia cordata } & + & + & - & - & -\end{array}$

Host not

indicated

Specimens

examined

167

46

86

31

Distribution fairly clearly southern: scattered in the Hemiboreal, Southern boreal and Middle boreal zones, only a few records from the southern parts of the Northern boreal zone. The host Populus tremula occurs throughout the country. The fungus is nowhere abundant, but even in the best sites is represented by single or imbricate fructifications, which seldom reappear in the subsequent seasons.

The host is almost exclusicely Populus tremula. The other three records are unconfirmed. The one from Betula may be true, since the collection included fruit bodies of Hapalopilus rutilans (Pers.) Karst., which in this area commonly occurs on birch, but only rarely on aspen. The record on Salix caprea is probably wrong, because thin, young trunks of $P$. tremula are common in the collection area (Etelä-Häme: Korpilahti, Vaarunvuori), and when dead are very difficult to distinguish from Salix caprea. We have no definite opinion regarding Tilia: this tree species should be rather easy to identify.

We know of only two cases in Finland in which the fruit bodies have emerged on a living tree. These were big aspen trees, growing vigorously and showing no signs of degeneration. The fruit bodies were attached close to almost healed branch scars on the trunk, occurring in the same way as Phellinus tremulae on that host. The characteristic substrates, however, are dead but still standing trunks of aspen, often relatively thin. The species is also found on big fallen branches of old trees, and less often on big trunks of rather recently fallen trees.

The ecological spectrum of the species is fairly wide. A characteristic site is a rocky hill sparsely wooded with pine and thin aspen (these trees often being rather old). It is also found in dense spruce forests intermixed with old aspen, in deciduous thickets at forest edges and in grass-herb forests.

It is of no economic importance, bacause of its rarity and concentration on aspen.
4

land, I. radiatus cannot be regarded as especially harmful. The reason is that the main hosts (Alnus and Corylus) are of little economic value. It causes some harm by decaying old lilacs in parks.

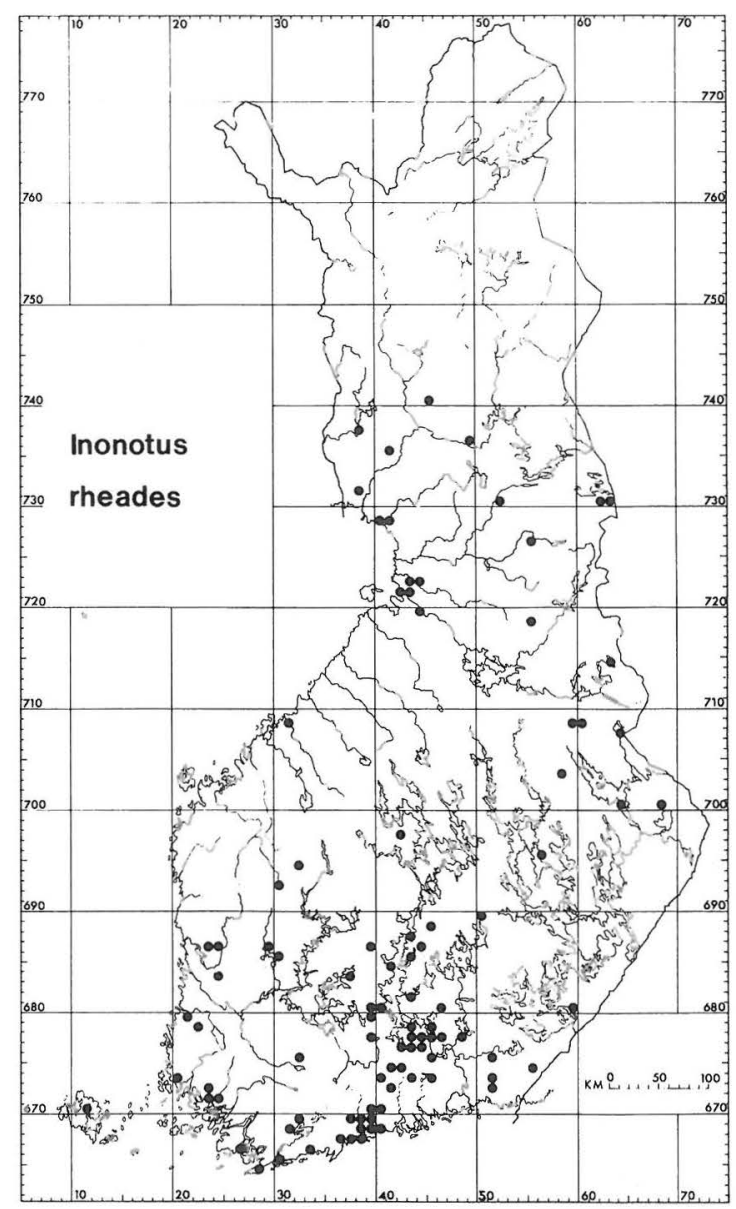


Onnia leporina (Fr.) Jahn

$\begin{array}{lccccc} & \begin{array}{c}\text { Whole of } \\ \text { Finland } \\ 100\end{array} & \text { U } & \text { EK-PK } & \text { KP-PP } & \text { Ks-InL } \\ \begin{array}{l}\text { Picea abies } \\ \begin{array}{l}\text { Host not } \\ \text { indicated }\end{array}\end{array} & 11 & & & & \\ \begin{array}{l}\text { Specimens } \\ \text { examined }\end{array} & 99 & 4 & 23 & 31 & 41\end{array}$

Not recorded from the Hemiboreal zone, occurring from the Southern boreal zone to the northernmost spruce stands in Lapland. The distribution has a distinct northern emphasis: in the Southern and Middle boreal zones only scattered occurrences are known in the best growth sites, while in the Northern boreal zone $O$. leporina is common and almost always found in suitable stands of spruce.

In the southern and central parts of Finland the occurrences are isolated and scanty, and there are almost no records of economic losses caused by this species. The only exceptions known to us are in the province of Etelä-Häme (national grid reference 68:3), where the fungus is locally abundant, e.g., around the town of Tampere and in the Sinivuori Nature Reserve, and also east of the lake Kyrösjärvi. In these places some old, dense spruce forests are relatively heavily infected, and the resultant death of standing trees and their subsequent fall have created small openings in the stand. However, these are restricted to very small areas.

In the Northern boreal zone the picture is completely different. O. leporina is one of the worst decaycausing agents in spruce forest, affecting all kinds of fully grown spruce stands. The species is a strong parasite, causing an intense corrosion rot of both sapwood and heartwood. The decay starts from the inner parts, and causes the death of the tree when it reaches the sapwood and cambium. In this final stage the decay progresses rather rapidly, and a characteristic, often abundant flow of resin is evident on the infected parts of the trunk. Most of the fruit bodies appear at this stage, though small groups are sometimes seen on weak but still living, standing trees. The fungus fruits during at least $5-10$ years after the death of the host, on both the stump and the fallen trunk. The amount of fructification depends on the summer weather conditions. The fruit bodies are mostly sessile, only exceptionally having a rudimentary stipe when growing on the upper side of a fallen trunk; they never grow on the ground like those of $O$. tometosa (cf. illustrations in Jahn 1978).

There are several records on the pathogenicity of o. leporina in these northern spruce forests. Eriksson (1958, as Coltricia tomentosa var. circinata) described its occurrence in the Muddus National Park in North Sweden, and later (Eriksson \& Strid 1969, sub n. Ino-

notus triqueter) compared the situation there with that in northern Finland. Norokorpi (1979, sub n. I. triqueter) regarded it as the second most common basidiomycete (after Coniophora arida (Fr.) Karst.) in butt-rot columns of spruce in North Finland.

Due to massive confusion in the nomenclature, it is difficult to make comparisons with the situation in North America. Judging from the species descriptions, one gets the impression that $O$. tomentosa is commoner and more harmful there, while $O$. leporina is economically less important (e.g., Whitney \& Bohaychuk 1976, 1977). Overholts (1953), however, re-

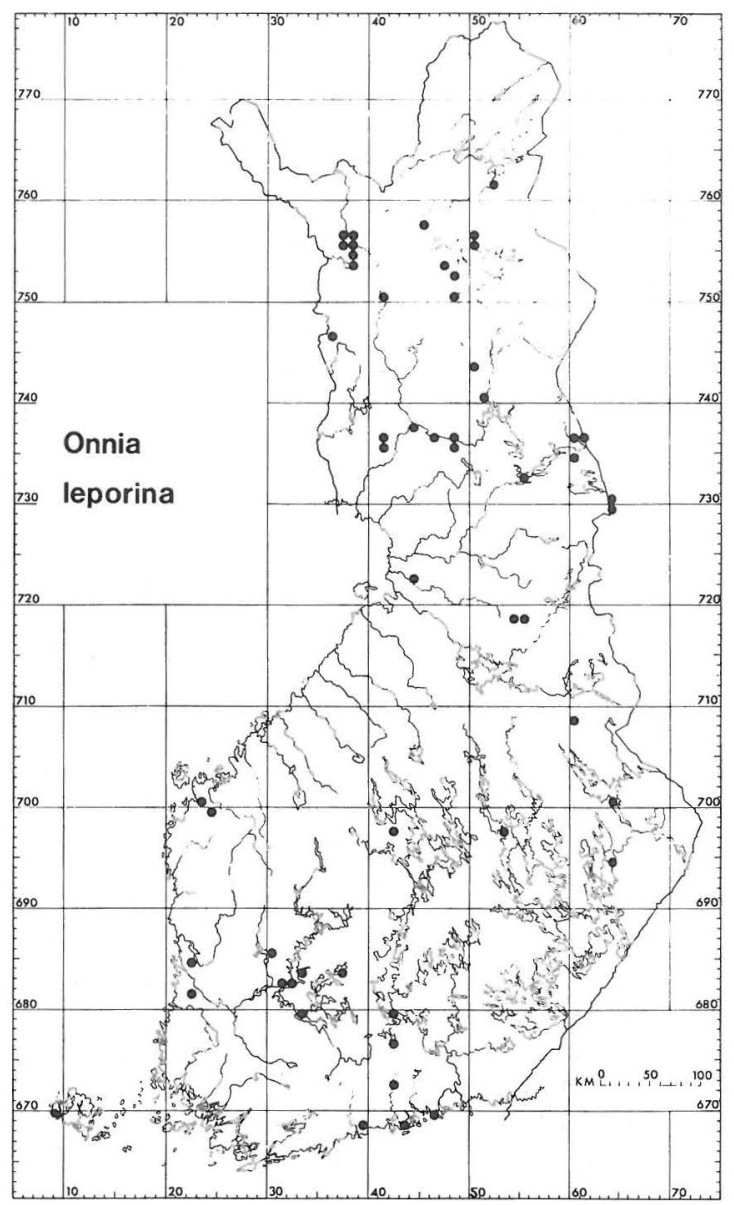


gards O. leporina (sub n. Polyporus tomentosus var. circinatus) as uncommon in the eastern states of the U.S.A. Great north-south differences may be expected to exist in the occurrence of the two species in North America also, though this does not seem to have been studied. In Europe these regional differences are clear: $O$. leporina is very rare in temperate western and Central Europe (Jahn 1978), and is still very rare in Poland (Domański et al. 1973). It gradually becomes commoner eastwards, first appearing sporadically in the montane areas of Czechoslovakia (Černý 1974).

O. leporina is often regarded as a member of the boreal-continental 'taiga species' complex (Eckblad 1981), other species being Amylocystis lapponica (Rom.) Sing., Fomitopsis rosea (Alb. \& Schwein.: Fr.) Karst., Phellinus chrysoloma (Fr.) Donk, P. ferrugineofuscus (Karst.) Bourd. and Phlebia centrifuga Karst. The nature of this complex has been discussed by Eriksson and Strid (1969) and some new aspects were presented by Kotiranta and Niemelä (1981).

$\begin{array}{lccc}\text { Onnia tomentosa (Fr.) } & \begin{array}{c}\text { Karst. } \\ \text { Whole of } \\ \text { Finland }\end{array} & \text { A-U } & \text { EH } \\ \text { Under Pinus sylvestris } & 11.8 & 8.3 & 20.0 \\ \text { Under Picea abies } & 5.9 & 8.3 & - \\ \text { Under hardwood } & + & + & - \\ \text { Ground: host unknown } & 79.4 & 79.2 & 80.0 \\ \text { Specimens examined } & 34 & 24 & 10\end{array}$

In Finland a distinctly southern species: most localities are in the Hemiboreal zone, and a few in the Southern boreal zone. Though it is rare, the existing occurrences are rather stable; they have persisted for many years and scores of fruit bodies appear when the growing season is suitable. In dry summers (e.g., 1982), almost no fructification occurs. Exclusively on the ground, under coniferous trees. Norokorpi (1979) reported it from northern Finland: Pohjois-Pohjanmaa. The record was based on culture only, and we (Kotiranta \& Niemelä 1981) have regarded it as a misidentification. One literature record from Åland (Stenlid 1947, Laine 1967) is indicated by an open square.

In the southern localities a characteristic growth site is around old pine trees, living or dead, in grassherb forest. The soil lacks a continuous moss cover, but dense grass-herb vegetation often makes it difficult to notice the fruit bodies. In some cases they have emerged for many years after the death and felling of the host pine. The northern growth sites have been rather different: dense, mostly virgin or old spruce forests with scattered pines over 500 years of age. The ground is covered with a relatively continuous carpet of moss: Dicranum polysetum, D. scoparium, Hyloco- mium splendens, Pleurozium schreberi, etc. In these growth sites, in particular, it is almost impossible to establish the host with certainty. The one record from under a hardwood species may originate from this kind of place, though not necessarily: it was made by Prof. Viljo Kujala (cf. Niemelä 1978), who was very accurate when making field notes. Occurrences in such sites in mossy spruce forest have also been observed by the author Niemelä in the Norra Kvill National Park, in the interior of South Sweden.

A root parasite and later saprophyte, $O$. tomentosa causes a white pocket rot in the roots and the lowest part of the trunk (Jahn 1978). Due to its rarity and occurrence mostly in protected forests, no economic lossess can be ascribed to this species in Finland. The situation is very different in northern North America, where $O$. tomentosa is one of the most widespread root-rotting fungi in Canada (Whitney 1980), e.g., in Saskatchewan, Ontario and Quebec (Whitney 1977), attacking the species of Picea (especially $P$. alba and P. mariana) and, less often, Abies, Larix, Pinus, Pseudotsuga, Thuja and Tsuga. The trees are killed and

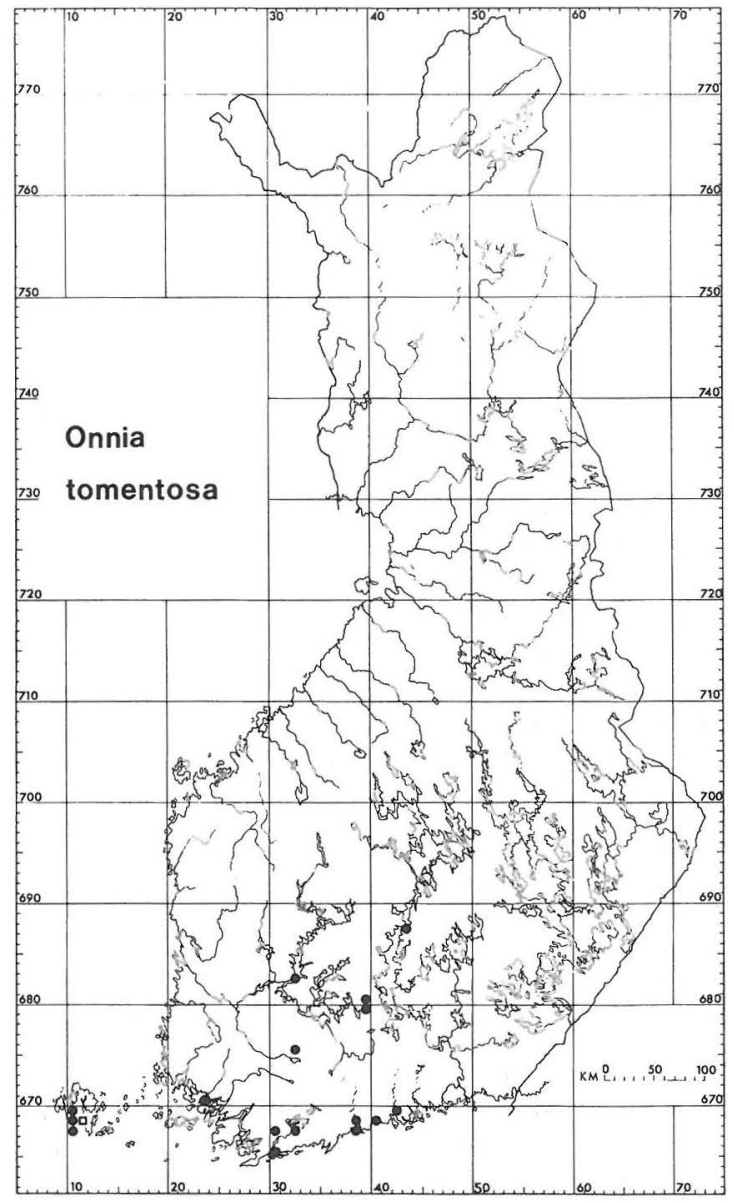


openings formed in the tree stand. The confusing nomenclature, however, makes it difficult to compare the species of this genus on the basis of the literature alone.

\section{Onnia triquetra (Lenz) Imazeki}

$\begin{array}{lr} & \text { EH } \\ \text { Pinus sylvestris } & + \\ \text { Specimens examined } & 1\end{array}$

This single Finnish record was discussed by Kotiranta and Niemelä (1981). Of the three European species of the genus, this is the most distinctly southern in its general distribution. The closest finds appear to be from southern Sweden (Jahn 1978). In contrast to $O$. leporina, $O$. triquetra is associated with pine.

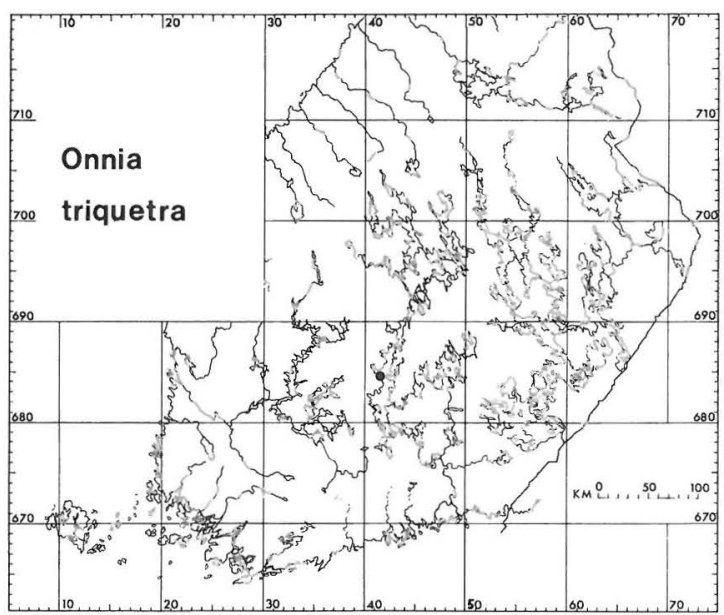

Some confusion has arisen regarding the correct form of the name. When describing the species, Fries (1836-1838: 474) himself wrote Polyporus triqueter. (For the correct author citations, see Jahn 1978) Since the change to the genus Onnia, both the forms triqueter and triquetra have been used. Dr. F. Kotlaba (Praha) drew our attention to this matter, and we had several discussions with him and with Mrs. Marja Kaila, M.A., Prof. Tuomo Pekkanen (via Mrs. Kaila) and Prof. Teuvo Ahti (all three from the University of Helsinki). After considering their opinions, we conclude that the correct form is Onnia triquetra. According to one view, the word triqueter stays unchanged in all genders. This cannot be accepted, however, because Fries (1849: 323) used the form triquetra when transferring the species to the genus Trametes (fem.). Later Karsten (1879) used the form Inoderma triquetrum, i.e., treated the epithet as a regular adjective. It seems that the form triqueter is an alternative spelling (orthographic variant) for the masculine form triquet- rus in classical Latin, the forms for the other genders being triquetra (fem.) and triquetrum (neuter). Some uninflected adjectives do exist in Latin, but none of them end in -er. The theory of the alternative spelling is supported by other examples, e.g., tener, asper and florifer (Stearn 1966: 93), and triqueter is understood as a normal adjective (not a noun) in the nomenclature of vascular plants (Stearn 1966: 533). The wrong practice (Donk 1974, etc.) derives from Imazeki (in Ito 1955), who failed to change the epithet triqueter when transferring the species from Polyporus (masc.) to Onnia (fem.). Hence Onnia triquetra.

Acknowledgements. This project was supported by a twoyear grant from the Academy of Finland. The curators of the herbaria are thanked for arranging the loans; in particular we wish to thank Dr. John Eriksson (Göteborg, Sweden) for the loan of the only North European specimen of Inonotopsis subiculosa. We are grateful to Dr. Maire Pyykkö (Helsinki) for identifying the host tree species of Coltricia cinnamomea, and to Dr. František Kotlaba (Praha, Czechoslovakia) for a note on the writing of the name Onnia triquetra. The activities of numerous collectors have contributed greatly to the completion of the maps, special thanks being due to Dr. Reino Alava (Turku), Dr. Lars Fagerström (Helsingfors), Mr. Veli Haikonen (Lahti) and Mr. Gustav Kvist (Helsingfors).

\section{Literature}

Černý, A. 1959: Inonotus nidus-pici Pilát, rezavec datlí, velmi škodlivý parasit některých listnatých dł̌evin $\mathrm{v}$ CSR. - Sborník Vys. Skol. Zeměd. Les. Brno 1959 (1): 65-87.

- 1965: Bionomie, rozšiření a hospodářský význam chorošú Inonotus nidus-pici Pilát a Inonotus obliquus (Pers. ex Fr.) Pilát v CSSR. - Sborník Nár. Muz. Praha 21B: 157-244.

- 1968: Phellinus pilatii sp.nov., ein sehr schädlicher Parasit an Populus alba L. und Populus canescens Smith. -Ceská Mykol. 22: 1-13.

- 1972: Phellinus tremulae (Bond.) Bond. \& Borisov, a most serious fungal parasite of aspen trees. - Acta Univ. Agric. Brno (Ser. C)41 (2): 131-149.

- 1974: Bionomie choroše Onnia circinata (Fr.) P. Karst., jeho hospodářský, význam a rošiření v Ceskoslovensku. - Lesnictvi 20: 203-218.

- 1982: Biologie rezavec Andersonova, Inonotus andersonii a jeho výskyt v Ceskoslovensku. - Ceská Mykol. 36: $11-19$.

Domański, S., Ortoś, H. \& SkirgieHo, A. 1973: Fungi: Polyporaceae 2, Mucronoporaceae 2, etc. $-332 \mathrm{pp}$., 27 pls. Warsaw.

Donk, M. 1974: Check list of European polypores. - 469 pp. Amsterdam \& London.

Eckblad, F.-E. 1981: Soppgeografi. - 168 pp. Oslo.

Eriksson, J. 1958: Studies in the Heterobasidiomycetes and Homobasidiomycetes-Aphyllophorales of Muddus $\mathrm{Na}-$ tional Park in North Sweden. - Symb. Bot. Upsalienses 16 (1): $1-172,24$ pls.

Eriksson, J. \& Strid, $\AA$. 1969: Studies in the Aphyllophorales (Basidiomycetes) of northern Finland. - Ann. Univ. Turku (A II) 40 (Rep. Kevo Subarctic Sta. 4): 112-158.

Fries, E. 1836-1838: Epicrisis systematis mycologici seu synopsis Hymenomycetum. - 610 pp. Upsaliae.

- 1849: Summa vegetabilium Scandinaviae... sectio posterior. - Pp. 259-572. Holmiae \& Lipsiae.

Ito, S. 1955: (Title in Japanese) Mycological flora of Japan 2(4): Auriculariales, Tremellales, Dacrymycetales, Aphyllophorales (Polyporales). $-450 \mathrm{pp}$. Tokyo. 
Jahn, H. 1978: Die Gattung Onnia P. Karst., Filzporlinge. - Westfäl. Pilzbriefe 11: 79-93.

Jülich, W. 1981: Higher taxa of Basidiomycetes. - 485 pp. Vaduz.

Karsten, P. 1879: Symbolae ad Mycologiam Fennicam 6. -Medd. Soc. Fauna Flora Fennica 5: 15-46.

- 1882: Rysslands, Finlands och den skandinaviska halföns hattsvampar 2. Pip-, tagg-, hud-, klubb- och gelésvampar. - Bidr. Känned. Finlands Natur Folk 37: 1-257.

- 1889: Kritisk öfversigt af Finlands basidsvampar (Basidiomycetes, Gastero- \& Hymenomycetes). - Bidr. Känned. Finlands Natur Folk 48: $1-470$.

Kier, L. 1961: Triterpenes of Poria obliqua. - J. Pharmaceut. Sci. 50: $471-474$.

Kotiranta, H. \& Niemelä, T. 1981: Composition of the polypore communities of four forest areas in southern Central Finland. - Karstenia 21: 31-48.

Laine, L. 1967: Notes on the polypores (Polyporaceae) of Ahvenanmaa. - Karstenia 6-7: 14-20.

Lowe, J. 1966: Polyporaceae of North America. The genus Poria. - State Univ. Coll. For. Syracuse Univ. Techn. Publ. 90: 1-183.

Marchand, A. 1976: Champignons du Nord et du Midi 4. Aphyllophorales (fin), Hydnaceae, Gasteromycetes \& Ascomycetes. -261 pp. Perpignan.

Niemelä, T. 1978: The occurrence of some rare pore fungi in Finland. - Ann. Bot. Fennici 15: 1-6.

- 1981: Polypores rare in or new to Finland. - Karstenia 21: 15-20.

- 1982: Polypore survey of Finland 1. Introduction. Karstenia 22: $21-26$.

- 1983: Northern forestline polypores. A comparison between northern Europe and north-eastern Canada. Manuscript.

Niemelä, T. \& Kotiranta, H. 1982: Polypore survey of Finland 2. The genus Phellinus. - Karstenia 22: 27-42.
Norokorpi, Y. 1979: Old Norway spruce stands, amount of decay and decay-causing microbes in northern Finland. - Metsäntutkimusl. Julk. 97 (6): 1-77.

Overholts, L. 1953: The Polyporaceae of the United States, Alaska, and Canada. - 466 pp. Ann Arbor.

Parmasto, E. 1973: Novyi rod Inonotopsis Parm. (sem. Hymenochaetaceae). - Folia Crypt. Estonica 2: 11-13.

Reid, D. 1976: Inonotus obliquus (Pers. ex Fr.) Pilát in Britain. - Trans. British Mycol. Soc. 67: 329-332.

Ryvarden, L. 1976: The Polyporaceae of North Europe 1. Albatrellus to Incrustoporia. - $214 \mathrm{pp}$. Oslo.

- 1978: The Polyporaceae of North Europe 2. Inonotus to Tyromyces. - Pp. 219-507. Oslo.

von Schulmann, O. 1955: Pilzstudien in Finnland. - Karstenia 3: $17-68$.

- 1960: Zur Kenntnis der Basidiomyceten Finnlands. Karstenia 5: 5-99.

Stearn, W. 1966: Botanical Latin, history, grammar, syntax, terminology and vocabulary. - $566 \mathrm{pp}$. London \& Edinburgh.

Stenlid, G. 1947: Några anteckningar om Ålands svampflora. - Mem. Soc. Fauna Flora Fennica 23: 82-90.

Whitney, R. 1977: Polyporus tomentosus root rot of conifers. - Fisher. Environm. Canada, Canad. Forestry Serv. Techn. Rep. 18: 1-12 (unnumbered).

- 1980: Polyporus tomentosus root and butt rot of trees in Canada. - In: Dimitri, L. (ed.), Proc. Fifth Int. Conf. Probl. Root \& Butt Rot of Conifers: 283-284. IUFRO, Kassel.

Whitney, R. \& Bohaychuk, W. 1976: Pathogenicity of Polyporus tomentosus and $\mathrm{P}$. tomentosus var. circinatus on seedlings of 11 conifer species. - Canad. J. Forestry Res. 6: 129-131.

- 1977: Variation of Polyporus tomentosus in cultural characteristics and pathogenicity on conifer seedlings. Canad. J. Bot. 55: 1389-1398. 